\title{
Screening and Characterization of Multi-Trait Plant Growth Promoting Bacteria Associated with Sugarcane for Their Prospects as Bioinoculants
}

\author{
B.H. Joshi ${ }^{1 *}$ and P.P. Joshi ${ }^{2}$ \\ ${ }^{1}$ Department of Food Quality Assurance, College of Food Processing Technology and \\ Bioenergy, Anand Agricultural University, Anand 388110 Gujarat, India \\ ${ }^{2}$ C.G. Bhakta Institute of Biotechnology, Gopal Vidyanagar, Bardoli Mahuva Road, Tarsadi, \\ Dist: Surat, Gujarat, India \\ *Corresponding author
}

\begin{tabular}{|c|c|}
\hline & A B S T R A C T \\
\hline & $\begin{array}{l}\text { Plant growth promoting bacteria has become of great interest to promote the crop growth } \\
\text { and protect from phytopathogens. Total of } 100 \text { bacterial isolates were obtained form } 45\end{array}$ \\
\hline Keywords & $\begin{array}{l}\text { different samples of rhizosphere soil as well as sugarcane parts. After extensive screening, } \\
\text { eight isolates found as potential for multiple PGP traits were further investigated for }\end{array}$ \\
\hline PGPR, Multi-trait, & cellulase, chitinase, HCN production potential and antifungal activity. Isolates F271 and \\
\hline $\begin{array}{l}\text { Bioinoculants, } \\
\text { Sugarcane. }\end{array}$ & S373were found to produce chitinase. $\mathrm{HCN}$ production was found in only F323 isolate. \\
\hline Article Info & followed by F181 and F373 isolates. Phosphate solubilization was found higher in F373 \\
\hline $\begin{array}{l}\text { Accepted: } \\
\text { 04 March } 2017 \\
\text { Available Online: } \\
10 \text { April } 2017\end{array}$ & $\begin{array}{l}\text { siderophore activity was found in all isolates under study except the ESB4. Protease } \\
\text { production was found higher in F181 isolate (19.5 IU), while other three isolate FF271, } \\
\text { ESB4 and F7373. Chitinase activity was found } 0.35 \mathrm{IU} \text { in F271 isolate while F373 was } \\
\text { also found to produce } 0.2 \mathrm{IU} \text { chitinase. Based on these results of screening three isolates }\end{array}$ \\
\hline & $\begin{array}{l}\text { F181, FF271 and F373 which shows multi-trait PGP activity isolated from the different } \\
\text { agro condition and popular varieties of sugarcane are selected for further study. } \\
\text { Characterization of these selected isolates identifiesF271 and F373 isolates as species of } \\
\text { Pseudomonas. While, isolate F181 was tentatively identified as Bacillus spp. }\end{array}$ \\
\hline
\end{tabular}

\section{Introduction}

Sugarcane is an important cash crop for several countries and it is mainly used for sugar and ethanol production. Sugarcane is the common name of a species of herb. The official classification of sugarcane is Saccharum officinarum, and it belongs to the family Gramineae. It is common in tropical and subtropical countries throughout the world. It is one of the principle crops of South
Gujarat and Saurashtra region of Gujarat state. This crop consumes heavy amount of nitrogen fertilizer and get affected by bacterial and fungal diseases for which chemical treatments are not recommended. Most of the countries use approximately 200$400 \mathrm{~kg} \mathrm{~N} \mathrm{ha}^{-1}$ which is costly and hazardous for environment. 
Applications of plant growth-promoting rhizobacteria (PGPR) can minimize the cost of fertilizer, environmental hazard, and suppress the diseases as well. PGPR are very well known for their role in plant growth promotion mainly for biological nitrogen fixation, phytohormone production, and acting as biocontrol agent. The exact mechanisms by which PGPR promote plant growth are not fully understood, but are thought to include (i) the ability to produce or change the concentration of plant growth regulators like indole acetic acid, gibberellic acid, cytokinins and ethylene (Arshad and Frankenberger, 1993; Glick, 1995), (ii) asymbiotic $\mathrm{N}_{2}$ fixation (Boddey and Dobereiner, 1995), (iii) antagonism against phytopathogenic microorganisms by production of siderophores (Scher and Baker, 1982), antibiotics (Shanahan et al., 1992) and cyanide (Flaishman et al., 1996), (iv) solubilization of mineral phosphates and other nutrients (De Freitas et al., 1997; Gaur, 1990). Another mechanism by which PGPR can inhibit fungal cell wall degrading enzymes, e.g., chitinase and B-1,3-glucanase.Biological control of soilborne plant pathogens and the synthesis of antibiotics have also been reported in several bacterial species. In addition to these traits, plant growth promoting bacterial strains must be rhizospheric competent, able to survive and colonize in the rhizospheric soil (Cattelan et al., 1999). Since associative interactions of plants and microorganisms must have come into existence as a result of coevolution, the use of latter group as bioinoculants must be preadapted, so that it fits into a longterm sustainable agricultural system. The challenge and goal is to be able to manage microbial communities to favor of plant colonization by beneficial bacteria. This would be amenable when a better knowledge on PGPR ecology and their molecular interactions is attained. The contributions of this research field may have economic and environmental impacts. A present study is to discover multiple PGPR traits that can act as biofertilizer and biocontrol agent for the popular varieties of sugarcane grown in South Gujarat region under different agro condition.

\section{Materials and Methods}

\section{Isolation of PGP bacteria}

Soil samples were collected from sugarcane rhizosphere from different villages of sugarcane growing region of Bardoli, Gujarat. Total of forty five samples were collected from different sites. Soil samples were collected at a depth of $5-10 \mathrm{~cm}$ according to v-shaped method. Samples were collected in aseptic begs and immediately transported to $\mathrm{lab}$ and maintained under cold condition $\left(4^{\circ} \mathrm{C}\right)$ for further process (Fatima et al., 2009). Sugarcane leaves and stems were collected from a 4 month old plantation. They were maintained in ice until analysis (Magnani et $a l ., 2010)$. One gram of each rhizospheric soil samples collected from different locations were suspended in $5 \mathrm{ml}$ sterile distilled water separately. After sedimentation of solid particles, dilutions were made up to $10^{-8}$ and $0.1 \mathrm{ml}$ of each dilution was spread by glass spreader on nutrient agar plates (peptone, 10 g; meat/beef extract, $3 \mathrm{~g}$; NaCl, $5 \mathrm{~g}$; distilled water, $1000 \mathrm{ml}$; agar, $15 \mathrm{~g}$; $\mathrm{pH}, 7.4)$. After 24 $\mathrm{h}$ of incubation at $30^{\circ} \mathrm{C}$ each distinct colony was further purified by streaking on nutrient agar plate (Fatima et al., 2009), the leaves and stem were washed with sterile distilled water and their surface disinfected by washing with $70 \%$ ethanol, after disinfection were flame sterilized. For the endophytic bacterial isolation, stems $(10 \mathrm{~g})$ and leaves $(10 \mathrm{~g})$ were macerated separately in sterile $10 \mathrm{mM}$ TrisHCL, $\mathrm{pH} 8.0$, and serially diluted to $10^{-6}$ dilutions. One hundred micro liters of these dilutions was inoculated on nutrient agar plate and incubated at room temperature for up to $48 \mathrm{~h}$. Each distinct colony was further 
purified by streaking on nutrient agar plate (Magnani et al., 2010). The isolated and purified colony was maintained on nutrient agar slant at $4 \stackrel{\circ}{\mathrm{C}}$ for further studies.

\section{Screening of PGP bacteria}

All isolates obtained from the different agro climatic regions with different popular varieties of sugarcane grown were studied for screening of diverge PGP traits.

\section{Antifungal activities}

For the screening of antifungal actinomycetes, different test organisms were evaluate against common sugarcane pathogens such as Aspergillus niger, Trichoderma viride and Fuserium oxysporium. These test organisms were grown in sterile potato dextrose broth for $74 \mathrm{~h}$. One milliliter of these cultures of each test organism was seeded in melted potato dextrose agar which was then poured in sterile Petri dish. After solidification of media spot inoculation of each bacterial isolate was carried out and incubated at $30^{\circ} \mathrm{C}$ for $72 \mathrm{~h}$. The antifungal bacteria show the zone of inhibition of the test organisms. Invitro antagonistic ability of bacterial isolates was investigated against sugarcane pathogen Fusarium moniliforme by dual culture technique (Rabindran and Vidhyasekaran, 1996). Bacterial isolates were streaked at one side of Petri dish ( $1 \mathrm{~cm}$ away from the edge) containing PDA (Potato infusion can be made by boiling $300 \mathrm{~g}$ of sliced (washed but unpeeled) potatoes in water for $30 \mathrm{~min}$ and then decanting or straining the broth through cheesecloth. Distilled water is added such that the total volume of the suspension is $11.20 \mathrm{~g}$ dextrose and $20 \mathrm{~g}$ agar powder is then added and the medium is sterilized by autoclaving at $15 \mathrm{p}$ for $15 \mathrm{~min}$ ). Five mm mycelia plug from seven day old PDA cultures of Fusarium moniliforme were placed at the opposite side of Petri dishes perpendicular to the isolate streak. Petri dishes were then incubated at $30^{\circ} \mathrm{C}$ for 5 days. Petri dishes inoculated with fungal discs alone were served as control. Observations on width of inhibition zone and mycelia growth of test pathogens were recorded.

\section{Protease}

Primary screening for protease producing bacterial isolates were carried out using skim milk agar medium. Spot inoculation of each actinomycetes isolate was carried out. The plates were incubated for $48 \mathrm{~h}$ at $30^{\circ} \mathrm{C}$. The halo around colonies confirmed the protease production ability of actinomycetes. Further these protease producers were evaluated for its quantitative production abilities. A loopful culture was inoculated into protease production medium followed by incubation at $48 \mathrm{~h}$ at $30^{\circ} \mathrm{C}$ in shaking condition. Filtrate was used for enzyme activity as described by using McDonald and Chen method (1965). A unit of protease activity may be defined as the amount of enzyme in $1 \mathrm{ml}$ of filtrate which under the conditions described hydrolyzes casein at such a rate that amount of hydrolysis products formed per min have the same optical density on reaction with phenol reagent as $1 \mu \mathrm{g} / 1$ tyrosine.

\section{Cellulase}

Each of the isolates was spot-seeded on mineral agar medium containing $1 \%$ carboxylmethyl cellulose to detect cellulases (Renwick et al., 1991). Those isolates which produced zone of clearance undergo were reconfirmed by quantitative assay. The quantitative estimation was carried out by inoculating a loopful culture into the cellulase production medium (mineral agar medium + $1 \% \mathrm{CMC}$ ). Incubation was carried out at $30^{\circ} \mathrm{C}$ for $72 \mathrm{~h}$ in shaking condition at $120 \mathrm{rpm}$. Then the filtrate was for determination of enzyme activity. Enzyme activity was 
measured using DNS method (Mandels et al., 1976). One unit of cellulase activity was defined as the amount of enzyme required to release $1 \mu \mathrm{mol}$ of glucose per min under these conditions (Mandels et al., 1976).

\section{Chitinase}

Each of the isolates was spot-seeded on a mineral agar medium containing $0.08 \%$ colloidal chitin to detect chitinases (Renwick et al., 1991). Those isolates which produced zone of clearance undergo for quantitative assay. A loopful culture was inoculated into the chitinase production medium consisting of (g/l) colloidal chitin, 10 ; peptone, $3 ; \mathrm{KNO}_{3}, 3$; $\mathrm{K}_{2} \mathrm{HPO}_{4}, 0.7 ; \mathrm{MgSO}_{4}, 0.5 ; \mathrm{KCL}$, 1. Then it was incubated at $30^{\circ} \mathrm{C}$ for $72 \mathrm{~h}$ in shaking condition at $120 \mathrm{rpm}$. Filtrate was used for enzyme activity. Chitinase activity was determined by a DNSA method (Miller et al., 1959). This method works on the concentration of $\mathrm{N}$-acetyl glucosamine (NAG), which is released as a result of enzymatic action (Massimiliano et al., 1998; Ulhoa et al., 1991).

\section{Siderophore production}

The screening for siderophore producing actinomycetes isolate were carried out by inoculated onto chrome azurol S (CAS) blue plates (Schwyn et al., 1987) with the modifications described previously (Fiss et al., 1990). The siderophore test was analyzed for the presence or absence of the orangeyellow halo surrounding the colonies, which indicated the presence or absence of a siderophore, respectively. Further quantitative estimation of siderophore was done by CASshuttle assay. In which cultures were inoculated $(1 \% \mathrm{v} / \mathrm{v})$ in sterile succinate medium (Meyer and Abdallah, 1978) separately and incubated on rotary shaker at $30 \mathrm{C}, 120 \mathrm{rpm}$. After $36 \mathrm{~h}$ of incubation, 0.5 $\mathrm{ml}$ of culture supernatant was mixed with 0.5 $\mathrm{ml}$ of CAS reagent, and absorbance was measured at $630 \mathrm{~nm}$.

$\%$ Siderophore Unit $=\frac{\mathrm{Ar}-\mathrm{As}}{\mathrm{Ar}} \times 100$

Where, $\mathrm{Ar}=$ absorbance of reference at 630 $\mathrm{nm}$ and $\mathrm{As}=$ absorbance of sample at $630 \mathrm{~nm}$

\section{IAA production}

IAA production by actinomycetes isolates were studied by colorimetric technique using Salkowaski reagent and orthophosphoric acid. Sterile nutrient broth containing tryptophane ( $2 \mathrm{mg} / \mathrm{ml}$ ) was inoculated with loopful culture of each actinomycetes isolate and incubated at $30^{\circ} \mathrm{C}$ in shaking condition at $120 \mathrm{rpm}$ for $48 \mathrm{~h}$. After that it was centrifuged at $1000 \mathrm{rpm}$ for 10 min. 2 drop of orthophosphoric acid and 4 $\mathrm{ml}$ Salkowaski reagent $(50 \mathrm{ml} 35 \%$ perchloric acid mixed with $1 \mathrm{ml}$ of $0.5 \%$ $\mathrm{FeCl}_{3}$ ) was added in $2 \mathrm{ml}$ of supernatant. It was incubated for $20 \mathrm{~min}$ at room temperature. Then the development of pink color was measured at $530 \mathrm{~nm}$ spectroscopy to confirm the IAA production.

\section{Phosphate solubilization}

Primary screening for phosphate solubilization was carried out on Pikovskaya's agar plate as described by Gaur (1990). Quantitative analysis of solubilization of tricalcium phosphate in liquid medium was carried out as described by King (1932). The potential isolates were inoculated in $25 \mathrm{ml}$ Pikovskaya's broth and incubated for 5 days at $30^{\circ} \mathrm{C}$. The actinomycetes cultures were centrifuged at $15,000 \mathrm{rpm}$ for $30 \mathrm{~min}$. One milliliter supernatant was mixed with $10 \mathrm{ml}$ of chloromoliblidic acid and volume was made up to $45 \mathrm{ml}$ with distilled water. The absorbance of developing colour was read at $600 \mathrm{~nm}$. The amount of phosphorous was detected from standard curve of $\mathrm{KH}_{2} \mathrm{PO}_{4}$. 


\section{HCN production}

All bacterial isolates were screened for the production of hydrogen cyanide by method described by Lorck (1948). The nutrient broth was amended with $4.4 \mathrm{~g}$ glycine/l and the isolates were streaked on modified agar plates. A Whatman filter paper no. 1 soaked in $2 \%$ sodium carbonate in $0.5 \%$ piciric acid was placed on the top of the plate. The plates were sealed with parafilm and incubated $30^{\circ} \mathrm{C}$ for 4 days. Development of orange to red colour indicated $\mathrm{HCN}$ production.

\section{Biological nitrogen fixation}

Screening of nitrogen fixing organisms was carried out by using semisolid malate medium (NFB) which include(malic acid, $5 \mathrm{~g}$; $\mathrm{KOH}, 4$ $\mathrm{g} ; \mathrm{K}_{2} \mathrm{HPO}_{4}, 0.5 \mathrm{~g} ; \mathrm{MgSO}_{4} \cdot 7 \mathrm{H}_{2} \mathrm{O}, 0.2 \mathrm{~g}$; $\mathrm{CaCl}_{2}, 0.02 \mathrm{~g} ; \mathrm{NaCl}, 0.1 \mathrm{~g} ; \mathrm{FeSO}_{4} \cdot 7 \mathrm{H}_{2} \mathrm{O}, 0.5$ g; $\mathrm{Na}_{2} \mathrm{MoO}_{4} \cdot 2 \mathrm{H}_{2} \mathrm{O}, 2 \mathrm{mg} ; \mathrm{MnSO}_{4} \cdot 7 \mathrm{H}_{2} \mathrm{O}, 10$ $\mathrm{mg} ; 0.5 \%$ alcoholic solution (or dissolved in $0.2 \mathrm{~N} \mathrm{KOH}$ ) of bromothymol blue, $2 \mathrm{ml}$; agar, $0.5 \% ; 1000 \mathrm{ml}$ distilled water, $\mathrm{pH}$ 6.8) (Döbereiner and Day, 1976). Growth of bacterial isolates in NFB medium indicates nitrogen fixation.

\section{Characterization of selected isolates}

\section{Characterization of the most efficient multi-trait PGP isolates}

The most efficient isolate was further characterized on the basis of its morphological, cultural and biochemical characteristics as per Bergey's Manual of Systematic Bacteriology (Holt et al., 1994). The morphological characteristics of the isolates studied included cell shape, size, arrangement of cells and Gram's nature. The cultural characteristics studied were colony morphology, exopolysaccharide production and pigmentation. The selected isolates were further subjected to the biochemical characterization for identification of organisms up to genus level.

\section{Results and Discussion}

\section{Isolation of rhizosphere and endophyte bacteria}

In present study, 45 samples were collected from different villages of Bardoli region (Table 1). From each farm eight soil samples was collected from different location of the farm including corner and center by random selection. For endophytic bacterial isolation 4 month old plantation were used and stem and leaves were collected from disease free plant. Total 100 isolates were obtained from different sites as shown in table 1.

For endophyte isolation, F6 site was selected. It was from Vihan village and sugarcane variety 86249 was grown. So far as endophytic bacteria are concerned, 8 different types of endophytic bacterial isolates were obtained, out of which 4 isolates from leaves and 4 isolates were from stem. Among all sites, F4 where 86032 sugarcane varieties grown were found enriched with the rhizospheric bacterial population. It is highly dependent to sugarcane variety and agro climatic factors. While F2 site where sugarcane variety 0411 was grown found poor for colonization of rhizospheric bacteria.

\section{Primary screening of PGPR}

All rhizospheric isolates were studied for its PGPR potential. For the same these 100 isolates were undergone primary screening for selected PGPR activities. The PGPR activities studies includes; IAA production, phosphate solubilization, siderophore production, Growth on $\mathrm{N}_{2}$ free medium and production of hydrolytic enzymes. The results of primary screening are summarized in table 2 and figure 1. 
All the isolates were investigated and compared for their various PGPR activities (Table 2). Primary screening of the rhizosphere and endophytic isolates shows many multi-trait PGP bacteria. The phosphate solubilizing and protease producing bacteria were found as the major dominant community. The site F5 was found to be well nourished with multi-trait PGP isolates. Almost $60 \%$ population was found to show multiple PGP activity.

Eight isolates from different sites have showed potential for multiple PGPR activities were selected and further investigated for other PGP traits such as cellulase, chitinase, $\mathrm{HCN}$ production potential and its antifungal activity (Table 3 ).

In further investigation none of the isolate was found having cellulase activities (Table 3). Two isolates F271 obtained from sample F2 and F373 obtained from sample F3 shown chitinase activity within 24 h. $\mathrm{HCN}$ production was only found in $\mathrm{F} 323$ isolate which was obtained from sample F3. Antifungal activity was not observed in all of the isolates under study.

Table.1 Isolation of Rhizosphere and endophytic bacteria from different locations

\begin{tabular}{lccccc}
\hline No. & Sampling site & $\begin{array}{c}\text { Sample } \\
\text { code }\end{array}$ & $\begin{array}{c}\text { Sugarcane } \\
\text { variety grown }\end{array}$ & $\begin{array}{c}\text { No. of sample } \\
\text { collected }\end{array}$ & $\begin{array}{c}\text { No. of isolates } \\
\text { obtained }\end{array}$ \\
\hline 1 & Sevani & F1 & 86032 & 08 & 16 \\
2 & Vansdarundhi & F2 & 0411 & 08 & 14 \\
3 & Vihan & F3 & 86249 & 08 & 21 \\
4 & Dhamdod & F4 & 86032 & 08 & 23 \\
5 & Bardoli & F5 & 0411 & 08 & 18 \\
6 & Vihan & F6 & 86249 & 05 & 08 \\
\hline
\end{tabular}

Table.2 Primary screening based on PGPR activities

\begin{tabular}{|c|c|c|c|c|c|c|}
\hline \multirow{2}{*}{$\begin{array}{l}\text { Sample } \\
\text { code }\end{array}$} & \multirow{2}{*}{$\begin{array}{l}\text { Sugarcane } \\
\text { variety } \\
\text { grown }\end{array}$} & \multicolumn{5}{|c|}{ Selected PGPR activities } \\
\hline & & $\begin{array}{l}\text { IAA } \\
\text { production }\end{array}$ & $\begin{array}{l}\text { Phosphate } \\
\text { solubilization }\end{array}$ & $\begin{array}{l}\text { Siderophore } \\
\text { production }\end{array}$ & $\begin{array}{l}\text { Nitrogen } \\
\text { fixation }\end{array}$ & $\begin{array}{l}\text { Protease } \\
\text { production }\end{array}$ \\
\hline F1 & 86032 & 07 & 12 & 04 & 07 & 11 \\
\hline $\mathrm{F} 2$ & 0411 & 09 & 11 & 05 & 04 & 11 \\
\hline F3 & 86249 & 12 & 16 & 06 & 14 & 17 \\
\hline $\mathrm{F} 4$ & 86032 & 10 & 05 & 07 & 10 & 08 \\
\hline F5 & 0411 & 17 & 12 & 10 & 15 & 13 \\
\hline F6 & 86249 & 04 & 05 & 07 & 07 & 05 \\
\hline Total is & ates:100 & 59 & 61 & 39 & 57 & 65 \\
\hline
\end{tabular}

Table.3 Primary screening of selected isolates for other PGPR traits

\begin{tabular}{lcccccccc}
\hline \multicolumn{1}{c}{ PGPR trait } & F181 & F271 & F323 & F372 & H373 & F531 & ELB1 & ESB4 \\
\hline Cellulase activity & - & - & - & - & - & - & - & - \\
Chitinase activity & - & + & - & - & + & - & - & - \\
HCN Production & - & - & + & - & - & - & - & - \\
Antifungal activity & - & - & - & - & - & - & - & - \\
\hline
\end{tabular}


Table.4 Characterization of selected multi-trait PGP isolates

\begin{tabular}{|c|c|c|c|}
\hline Isolates & F181 & F271 & F323 \\
\hline \multicolumn{4}{|c|}{ Morphological Characteristics } \\
\hline Size & Small & Large & Small \\
\hline Shape & Rod & Rod & Rod \\
\hline Arrangement & Single & Single & Single \\
\hline Gram's nature & Positive & Negative & Negative \\
\hline \multicolumn{4}{|l|}{ Cultural Characteristics } \\
\hline Size & Small & Large & Small \\
\hline Shape & Round & Round & Round \\
\hline Margin & Entire & Entire & Entire \\
\hline Opacity & Translucent & Opaque & Opaque \\
\hline Elevation & Raised & Convex & Flat \\
\hline Consistency & Moist & Dry & Moist \\
\hline Colour & Nil & Green & Green \\
\hline Optimum $\mathrm{pH}_{\mathrm{o}}$ for Growth & 7 & 7 & 7 \\
\hline \multicolumn{4}{|l|}{ Growthat ( C) } \\
\hline 4 & + & + & + \\
\hline 30 & ++ & ++ & ++ \\
\hline 40 & + & - & - \\
\hline \multicolumn{4}{|l|}{ Biochemical Characteristics } \\
\hline \multicolumn{4}{|l|}{ Utilization of: } \\
\hline Glucose & + & + & + \\
\hline Maltose & + & + & - \\
\hline Lactose & - & + & + \\
\hline Mannitol & + & - & - \\
\hline Xylose & - & + & + \\
\hline Sucrose & - & - & - \\
\hline Methyl red test & - & - & - \\
\hline Voges-Proskauer test & + & - & - \\
\hline Oxidase test & - & + & + \\
\hline Citrate utilization & + & + & + \\
\hline Indole production & + & - & - \\
\hline Urea hydrolysis & + & - & - \\
\hline $\mathrm{H}_{2} \mathrm{~S}$ Production & - & - & - \\
\hline Phenyl alanine deamination & - & - & - \\
\hline Nitrate reduction & + & + & + \\
\hline Ammonia production & + & - & - \\
\hline Gelatin hydrolysis & + & + & + \\
\hline Catalase & + & + & + \\
\hline Growth on TSI slant & NA & - & - \\
\hline
\end{tabular}

Positive: +; Negative: - 
Fig.1 Primary screening for various PGP traits; a. sederophore production, b. Growth on N2 free medium, c. Protease production, d. Phosphate solubilization, e. IAA production and e. HCN production

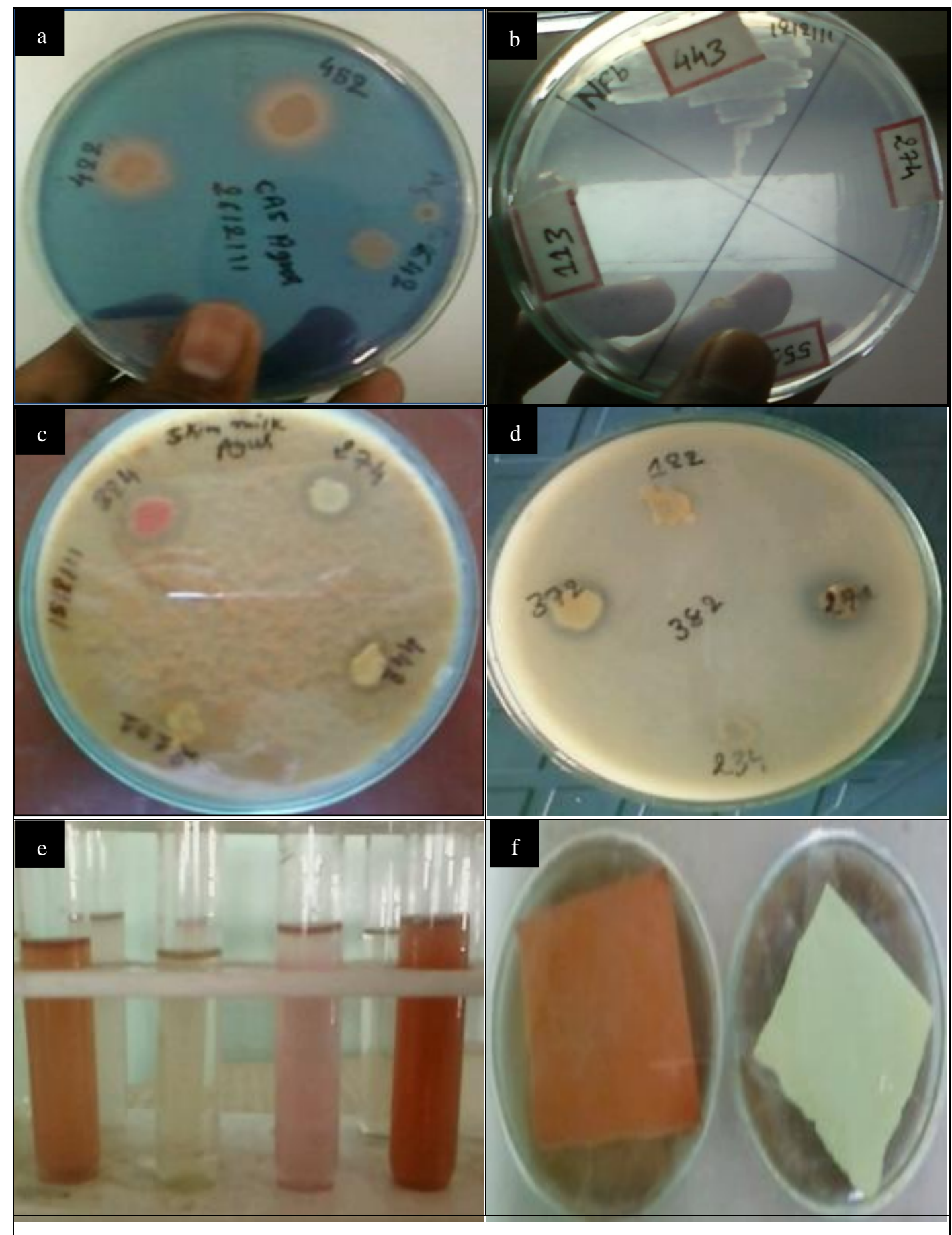




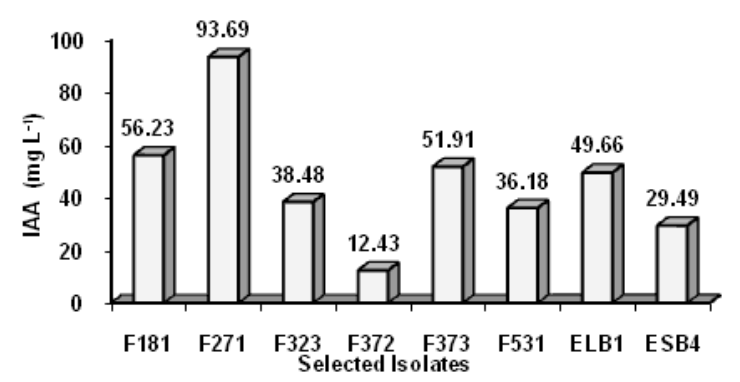

Fig.2 IAA production by selected multi-trait PGP bacterial isolates

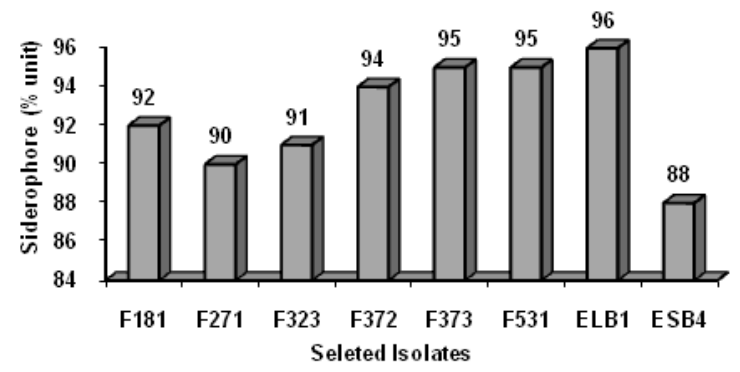

Fig.4 Siderophore production by selected multitrait PGP bacterial isolates

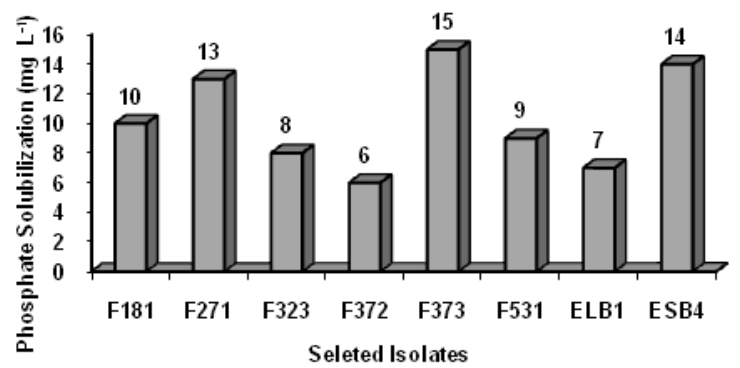

Fig.3 Phosphate solubilization by selected multi-trait PGP bacterial isolates

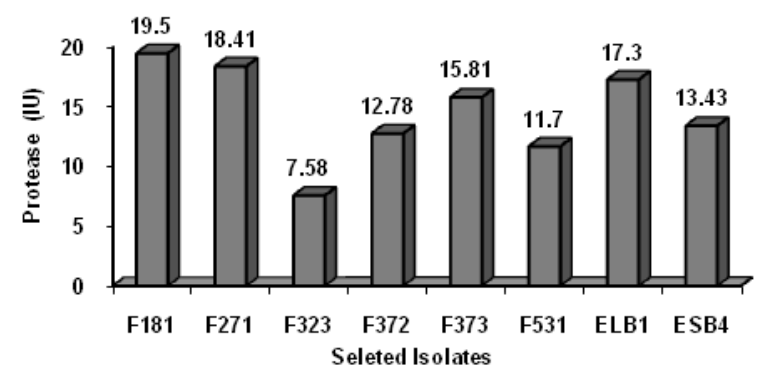

Fig.5 Protease production by selected multitrait PGP bacterial isolates

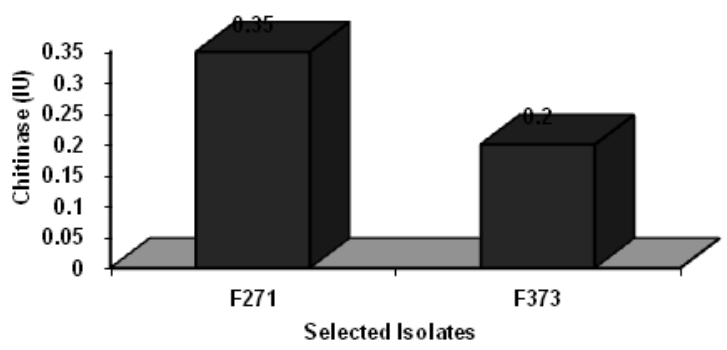

Fig.6 Chitinase production by selected multi-trait PGP bacterial isolates

\section{Secondary screening of PGPR}

Once the PGPR potential of all isolates was recognized, they were further subjected to detailed investigation about their quantitative ability for the respective PGPR activities. These secondary screening was carried for selected most efficient isolates having multitrait PGP activities includes IAA production, phosphate solubilization, siderophore, protease and chitinase production.

\section{IAA production}

Quantification of IAA was carried out for eight selected isolates with multiple PGP activities. Results are summarized in figure 2. F181, F271 F373 and ELB1 found to produce significant amount of IAA. Highest amount of IAA was produced (93.69 $\mathrm{mg} \mathrm{L}^{-1}$ ) by F271 isolate. F181 and F373 were found to produce more than $50 \mathrm{mg} \mathrm{L}^{-1}$ of IAA. 


\section{Phosphate solubilization}

All 8 isolates found show multiple PGPR activities were investigated for phosphate solubilizing capacity quantitatively. Among all eight isolates F373 was found best isolates as phosphate solubiliser. It had solubilized 15 $\mathrm{mg} \mathrm{L}^{-1}$ phosphate after four days incubation (Fig. 3). Isolates F181, F271 and ESB4 (endophyte) were also considered as a potential phosphate soubilizer as they were found to solubilize phosphate more than 10 $\mathrm{mg} \mathrm{L^{-1 }}$.

\section{Siderophore production}

All 8 isolates were quantitatively analyzed for siderophore production. All the isolates were found good siderophore producer as they produced siderophore production more than $80 \%$ unit (Fig. 4). Highest production of siderophore was estimated in ELB1 (endophytic isolates) that was $96 \%$ while ESB4 production was found in F271 isolate that was $88 \%$. F181, F323, F372, F373, F531 and F271 (endophyte) were also found as good siderophore producer.

\section{Protease production}

Production of protease is one of the antipathogenic mechanisms produced by PGPR as it degrades the cell wall of other pathogenic organism. All selected 8 isolate were analyzed for quantitatively for protease production. Protease production was found highest that was 19.5 IU in F181 isolate (Fig. 5). F373, F372 and F531 were found other good protease producer. Both the entophytes were also found good protease producer.

\section{Chitinase production}

Production of chitinase also serve antibacterial function as it play role in cell wall degradation of pathogenic organism.
Two isolate were obtained positive in primary screening were analyzed quantitatively for chitinase production. Out of eight isolates only two isolates shows chitinase activity (Fig. 6). F271 had found produced 0.35 IU while F273 was found to produce 0.2 IU. Both these two isolates were found significant IAA producer as well as siderophore producer.

PGP isolates F181 and F737 found to produce significant amount of multiple PGP traits such as protease, siderophore production, phosphate solubilization, IAA production and chitinase production. So such isolate can be utilized as bioinoculants for biofertilizer as well as biocontrol agent for commercial aspect. F271 was found also to produce good quantity of IAA, siderophore production and phosphate solubilization while not found potential for significant protease and chitinase production.

The various mechanisms involved in plant promotion may be host plant-specific and strain specific. Furthermore, once introduced into the soil, PGP bacteria face competitive conditions that may severely reduce their beneficial effects (Bashan, 1998). Therefore, the beneficial effects deriving from the application of a specific bio inoculant may differ greatly under different agro environmental conditions and this has resulted in contesting the efficacy of microbial-based products (Cummings, 2009; Owen et al., 2015). The assurance of efficacy for a biofertilizer in a particular soil with a specific variety of crop is thus a complex task, which shall be considered by researchers, manufacturers, agricultural advisors and farmers when designing and applying a specific biofertilizer: a challenge to transform the fertilization with these products into a common practice for twenty-first century agriculture. Considering these facts the consortium of bacteria with multi-trait PGP 
activity is the viable solution. Considering different agro environmental condition and the type of sugarcane variety grown as crucial factor for the effective development of the bio inoculant, extensive screening programme for the multi-trait PGP bacteria from different agro environmental conditions where different sugarcane varieties grown is attempted. Each of the most potential bacterial isolate shown multi-trait PGP activities under this agro climatic condition with varietal specificity was selected for their further characterization for the identification. The results confirm three isolates F181, F271 and F373 as important candidates of consortium which assures the sugarcane growth promotion under different varietal and agro conditions of the south Gujarat region.

\section{Characterization of isolates}

Three selected isolates having multi-trait PGP activities are studied for their characterization. Isolate F181 was Gram positive while other two isolates of the isolates were Gram negative bacteria (Table 4). All the isolates were found to having a rod shape and single arrangement. For physiological characterization bacterial isolates were subjected to growth at different temperature and different $\mathrm{pH}$. The optimum $\mathrm{pH}$ and temperature for the growth of all isolates under study were 7 and $30^{\circ} \mathrm{c}$ respectively. Cultural characteristics were studied for all selected isolates. Results are summarized in table 4 . The F181 isolate was positive for gelatin liquefaction, casein hydrolysis, indole production, catalase test, starch hydrolysis, urease test and denitrification activity. It has showed growth at $40^{\circ} \mathrm{C}$. Based on morphological cultural and biochemical characteristics, F181 isolate was tentatively identified as Bacillus spp (Table 4). While, isolates F271 and F373 were found to produce green pigment, similar to Pseudomonas spp. They were catalase and oxidase positive, showing growth at either of the extreme temperatures, $4^{\circ} \mathrm{C}$ and $40^{\circ} \mathrm{C}$ and also displayed oxidative utilization of glucose. Based on these typical characteristics, they are identified as Pseudomonas species (Holt et al., 1994).

In conclusion this extensive isolation and screening of bacterial diversity from the sugarcane varieties grown in Bardoli region would be significantly reveled potential isolates with significant multiple PGPR activities. Three most efficient isolates, F181, F271 and F373 were characterized as species of Bacillus and Pseudomonas isolated from rhizosphere of sugarcane having multiple PGP activities such as IAA production, phosphate solubilization, siderophore production, nitrogen fixation, $\mathrm{HCN}$ production, hydrolytic enzymes production which could be ideal candidate for the consortium of bacteria as bio innoculants for nourishing the soil with biocontrol attributes for the popular varieties of sugarcane under the diverge agro conditions of South Gujarat region. Further studies should be focused on the detailed molecular and functional characterization of these PGPR for practical applications in the field.

\section{References}

Arshad, M. and Frankenberger, W.T., Jr., 1993. Microbial Production of Plant Growth Regulators. In: "Soil Microbial Ecology",(Eds.): Blaine, F. and Metting, Jr., Marcel and Dekker, Inc., New York, pp. 307-347.

Bashan, Y. 1998. Inoculants of Plant GrowthPromoting Bacteria for Use in Agriculture. Biotechnol. Adv., 16: 729770.

Boddey, R.M. and Dobereiner, J. 1995. Nitrogen Fixation Associated with Grasses and Cereals: Recent Progress 
and Perspectives for the Future. Fert. Res., 42: 241-250.

Castric, P. 1977. Glycine Metabolism of Pseudomonas aeruginosa: Hydrogen Cyanide Biosynthesis. J. Bacteriol., 130: 826-831.

Cattelan, A.J., Hartel, P.G. and Fuhrmann, J.J. 1999. Screening of Plant Growth Promoting Rhizobacteria to Promote Early Soybean Growth. Soil Sci. Soc. Am. J., 63: 1670-1680.

Cummings, S.P. 2009. The Application of Plant Growth Promoting Rhizobacteria (PGPR) in Low Input and Organic Cultivation of Graminaceous Crops; Potential and Problems. Environ. Biotechnol., 5: 43-50.

De Freitas, J.R., Banerjee, M.R. andGermida, J.J. 1997. Phosphate Solubilizing RhizobacteriaEnhance the Growth and Yield but not Phosphorus Uptake of Canola (Brassica napus L.). Biol. Fertil. Soil., 24: 358-364.

Döbereiner, J. and Day, J.M. 1976. Associative Symbioses in Tropical Grasses: Characterization of Microorganisms and Dinitrogen-fixing

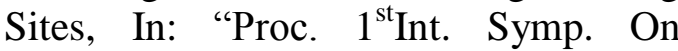
Nitrogen Fixation", (Eds.): Newton, W. E. and Nyman, C. J., Washington State University Press, Pullman, U.S.A., pp. 518.

Fiss, E. 1990. Modification of the Chrome Azurol S Medium for Detection of Siderophore Production by Mycobacteria, In: Abstr., 90 ${ }^{\text {th }}$ Annu. Meet. Am. Soc. Microbiol., Washington, D.C. U-73, pp. 153.

Flaishman, M.A., Eyal, Z.A., Zilberstein, A., Voisard, C. and Hass, D. 1996. Suppression of Septoriatritci blotch and Leaf Rust of Wheat by Recombinant Cyanide Producing strains of Pseudomonas putida. Mol. Plant Microbe Interact., 9: 642-645.
Gaur, A.C. 1990. Physiological Functions of Phosphate Solubilizing Microorganisms. In: Gaur, A.C. (Ed.): Phosphate Solubilizing Microorganisms as Biofertilizers. Omega Scientific Publishers, New Delhi, pp. 16-72.

Glick, B.R. 1995. The Enhancement of Plant Growth by Free Living Bacteria. Can. J. Microbiol., 41: 109-114.

Holt, J.G., N.R. Krieg, P. Sneath, J. Staley, and Williams, S. 1994. Bergey'sManual of Determinative Bacteriology, $9^{\text {th }}$ ed. Baltimore, MD: Williams and Wilkins. pp.787.

King, E.D., Ward, M.K., and Raney, D.E. 1954. Two Simple Media for the Demonstration of Pyocyanin and Fluorescin, J. Lab. Clin., Med., 44: 301307.

Lorck, H.1948. Production of Hydrocyanic acid by Bacteria. Physiol. Plant., 1: 142-146.

Magnani, G.S., Didonet, C.M., Cruz, L.M. Pcheth, C.F., Pedrosa, F.O. and Souza, E.M. 2010. Diversity of Endophytic Bacteria in Brazilian Sugarcane. Genet. Mol. Res., 9(1): 250-280.

Mandels, M., Andreotti, R. and Roche, C. 1976. Measurement of Saccharifying Cellulase. Biotechnol. Bioeng. Symp., 6: 21-33.

Massimiliano, F., Jean-Louis, L., and Federici, F. 1998. Chitinolytic Enzymes Activity of Penicillium janthinellum P9 in Bench Top Bioreactor. J. Ferment. Bioeng., 86: 620-622.

McDonald, C.E. and Chen, L.L. 1965. Lowry modification of the Folin reagent for determination of proteinase activity, Anal. Biochem., 10: 175-177.

Meyer, J.M. and Abdallah, M.A. 1978. The Fluorescent Pigments of Fluorescent Pseudomonas:

Biosynthesis, Purification and Physicochemical 
Properties, J. Gen. Microbiol., 107: 319-328.

Miller, C.M., Miller, R.V., Kenny, D.G., Redgrave, B., Sears, J., Condron, M.M., Teplow, D.B., and Strobel, G.A. 1998. Ecomycins, Unique Antimycotics from Pseudomonas viridiflava. J. Appl. Microbiol., 84: 937-944.

Owen, D., Williams, A.P., Griffith, G. W. and Withers, P.J.A. 2015. Use of Commercial Bio-Inoculants to Increase Agricultural Production Through Improved Phosphorus Acquisition. Appl. Soil Ecol., 86: 41-54.

Rabindran, R. and Vidhyasekaran, P. 1996. Development of a Formulation of Pseudomonas fluorescens Pfalr2 For Management of Rice Sheath Blight. Crop Protection, 15: 715-721.

Renwick, A., Campbell, R. and Coe, S. 1991. Assessment of in vitroScreening Systems for Potential Biocontrol agents of Gaeumannomyces graminis. Plant Pathol., 40: 524-532.

Scher, F.M., Baker, R., 1982. Effect of Pseudomonas putida and a Synthetic Iron Chelator on Induction of Soil
Suppressiveness to Fusarium Wilt Pathogens. Phytopathol., 72: 15671573.

Schwyn, B.C. and Neilands, J.B. 1987. Universal Chemical Assay for the Detection and Determination of Siderophores. Anal. Biochem., 160: 4756.

Shanahan, P., O'Sullivan, D.J., Simpson, P., Glennon, J.D. and O'Gara, F. 1992. Isolation of 2,4-diacetylphlorogucinol from a Fluorescent Pseudomonad and Investigation of Physiological Parameters Influencing its Production. Appl. Environ. Microbiol., 58: 353-358.

Ulhoa C.J. and Peberdy, J.F. 1991. Regulation of Chitinase Synthesis in Serratia marcescens. J. Gen. Microbiol., 14: 2163-2169.

Zarrin Fatima, M., Saleemi, Muhammad Zia, T., Sultan, M., Aslam, Riaz-Ur-Rehman and Fayyaz Chaudhary, M. 2009. Antifungal Activity of Plant Growth Promoting Rhizobacteria isolates Against Rhizoctonia solani in Wheat. Afr. J. Biotechnol., 8(2): 219-225.

\section{How to cite this article:}

Joshi, B.H. and Joshi, P.P. 2017. Screening and Characterization of Multi-Trait Plant Growth Promoting Bacteria Associated with Sugarcane for Their Prospects as Bioinoculants. Int.J.Curr.Microbiol.App.Sci. 6(4): 240-252. doi: https://doi.org/10.20546/ijcmas.2017.604.028 